Andrzej Kacprzak

Instytut Socjologii

Wydział Ekonomiczno-Socjologiczny

Uniwersytet Łódzki

\title{
RODZINNE UWARUNKOWANIA PRZESTĘPCZOŚCI NIELETNICH W ŚWIETLE KRYMINOLOGICZNYCH TEORII NIEFORMALNEJ KONTROLI SPOŁECZNEJ
}

\section{WPROWADZENIE}

Przestępczość nieletnich, będąca szczególną kategorią zachowań definiowanych przez kodeks karny jako niezgodne z prawem ${ }^{1}$, jest zjawiskiem stanowiącym przedmiot refleksji interdyscyplinarnej, angażującym przedstawicieli takich m.in. dyscyplin i subdyscyplin z obszaru nauk społecznych, jak psychologia rozwojowa, pedagogika resocjalizacyjna, socjologia problemów społecznych, socjologia dewiacji czy wreszcie kryminologia. Ponadto, mnogość polskich i zagranicznych opracowań zajmujących się problematyką czynów karanych popełnianych przez osoby nieletnie świadczy o tym, że problem ten od wielu lat cieszy się niesłabnącym zainteresowaniem badawczy. Za B. Hołystem (2009: 435) można wskazać co najmniej trzy główne przyczyny zainteresowania naukowego problematyką przestępczości nieletnich. Po pierwsze, ze względu na szczególnie wysoki poziom wrażliwości społecznej w kwestiach związanych z przejawami „wykolejenia spo-

${ }^{1}$ W świetle polskiego prawa karnego za nieletnie uznaje się osoby, które nie ukończyły 17. roku życia. Sam termin ,przestępczość nieletnich” może jednak budzić pewne zastrzeżenia, a nawet - jak wskazują Błachut i in. - wprowadzać w błąd. Zdaje się bowiem sugerować, że określone w ten sposób zachowania osób nieletnich zasługują na takie samo traktowanie, jak zachowania dorosłych, podczas gdy k.k.w. nie przewiduje możliwości zastosowania wobec osoby nieletniej tych samych środków oddziaływania. Termin ten wszedł jednak do powszechnego użytku zarówno w języku potocznym, jak i naukowym, w tym prawniczym. W języku polskim brak jest aktualnie lepszego (tj. takiego, co do którego panowałaby powszechna zgodność) określenia niż „przestępczość" nieletnich, niezależnie od tego, że wchodzące w obręb tego pojęcia „ujemne” zachowania młodzieży uznaje się de facto za wymagające interwencji sądu. Niezależnie od tego, nieletni nie są jednak w świetle polskiego prawa przestępcami, lecz sprawcami czynów karalnych (Błachut, Gaberle, Krajewski, 2004: 317). 
łecznego" przedstawicieli młodego pokolenia, który warunkuje przede wszystkim antycypacja dalszych etapów tego procesu oraz przekonanie o konieczności podejmowania działalności profilaktycznej w tym zakresie. Innymi słowy, wczesne przejawy nieprzystosowania społecznego są na ogół interpretowane przez społeczne audytorium jako ostrzeżenie przed dalszym postępem procesu wykolejenia. Pogląd ten jest dodatkowo wzmacniany przez dostrzegalne ryzyko zasilenia w przyszłości źródeł przestępczości dorosłych (Nowak, Wysocka 2001: 115). Po drugie, w badaniach i analizach poświęconych problematyce przestępczości nieletnich zwraca się na ogół uwagę na duże nadzieje resocjalizacyjne wiązane z ludźmi młodymi, co uzasadnić można relatywnie mniejszym stopniem ich „demoralizacji” i tym samym analogicznie większą skutecznością ewentualnych oddziaływań korekcyjnych (np. w porównaniu z przebywającymi w zakładach karnych, zaangażowanymi w więzienne „drugie życie” recydywistami), szerszym dostępem do zasobów i odpowiednio większym zakresem możliwości edukacyjnych, zawodowych i społecznych. Trzecim istotnym powodem koncentracji uwagi na zachowaniach przestępczych młodzieży jest możliwość precyzyjniejszego, niż w przypadku przestępców dorosłych, określenia przyczyn wchodzenia na drogę kolizji z prawem, czyli tzw. kryminogenezy. Przyjmuje się, iż wartość eksplanacyjna doświadczeń młodzieży w kontekście analizy czynników popychających jednostkę w stronę konfliktu z prawem jest znacznie większa ze względu na relatywną „świeżość” (z poznawczego punktu widzenia) danych. Badacze zajmujący się problematyką etiologii zachowań przestępczych dostrzegają zatem szerszą gamę możliwości w zakresie obserwacji czynników etiologicznych zachowań przestępczych. W literaturze przedmiotu znaleźć można bogaty materiał poświęcony analizie przyczyn przestępczości nieletnich. Wśród czynników kryminogennych wyróżnia się najczęściej tzw. endogenne (wewnętrzne), których wyjaśnienie znajdujemy w koncepcjach biologicznych i psychologicznych, oraz tzw. egzogenne (zewnętrzne), będące przedmiotem zainteresowania socjologów ${ }^{2}$. W ramach prowadzonych analiz dotyczących przestępczości nieletnich szczególną uwagę zwraca się na dwie uogólnione grupy czynników, związane z funkcjonowanie w ramach dwóch najważniejszych środowisk socjalizujących: rodziny oraz szkoły i grup rówieśniczych ${ }^{3}$.

Tematyka niniejszego opracowania mieści się w ostatnim $\mathrm{z}$ wymienionych obszarów, zaś celem w nim podjętym jest charakterystyka rodzinnych uwarun-

${ }^{2}$ W ramach kryminologii najczęściej mamy do czynienia z rozłącznymi analizami psychologicznymi lub socjologicznymi, rzadziej natomiast spotkać można ujęcia poszukujące kompromisu. Sub-dziedziną, której udało się go odnaleźć w sposób najpełniejszy jest psychologia społeczna zachowań przestępczych (social psychology of offending) (zob. Jefferson, 2010).

${ }^{3} \mathrm{~W}$ analizach zjawiska przestępczości nieletnich grupy rówieśnicze oraz życie szkolne są niekiedy traktowane jako dwie odrębne grupy czynników (zob. np. Błachut, Gaberle, Krajewski 2004: 348-57; 361-368). 
kowań wchodzenia na drogę konfliktu z prawem przez osoby nieletnie, przy wykorzystaniu dorobku teoretycznego przedstawicieli nurtu nieformalnej kontroli społecznej. Tekst ten jest jednocześnie próbą zwrócenia uwagi na sytuację rodzinną nieletnich sprawców czynów karanych, jako szczególnie istotną w kontekście analiz współczesnych procesów wykluczania społecznego oraz reintegracji społecznej grup i kategorii doświadczających poważnych deficytów w organizacji środków do życia. Sytuacja rodzinna nieletnich będzie wobec tego rozważana jako: a) jedna z najważniejszych grup czynników korelujących (w sposób dodatni lub ujemny) z procesem wchodzenia przez nieletnich na drogę konfliktu z prawem, b) jeden z możliwych czynników zmiany zachowań przestępczych w cyklu życia, tj. „wycofania” z działalności przestępczej (desistance).

\section{KONTROLA SPOŁECZNA I WIĘŹ SPOŁECZNA A PROCES KRYMINOGENEZY}

Kluczową kategorią analityczną w kontekście rozważań na temat przyczyn wchodzenia przez osoby nieletnie w konflikt z prawem są jej stosunki z najbliższym otoczeniem, rozumiane jako siła więzi ze środowiskami socjalizującymi. Stąd też w analizach zjawiska przestępczości nieletnich na pierwszy plan wysuwa się sytuację rodzinną oraz funkcjonowanie jednostki w ramach szkoły i grup rówieśniczych. W ujęciu proponowanym przez kierunek kontroli społecznej w ramach socjologii dewiacji, dynamika więzi społecznej jako podstawowego elementu kontroli społecznej pozostaje w ścisłej relacji z zachowaniami o charakterze przestępczym, wpływając na nie w sposób bezpośredni i jednokierunkowy.

Zgodnie z reprezentatywną dla całego nurtu kontroli społecznej (Siemaszko 1993) teorią sformułowaną przez T. Hirschiego (1969), wyróżnić można cztery podstawowe elementy więzi społecznej jednostki z otoczeniem, spełniające funkcję prewencyjną wobec zachowań przestępczych. Podstawową jednostką symboliczną przyczyniającą się do przestrzegania przez jednostkę norm społecznych, w tym także tych o charakterze formalnoprawnym, są jej emocjonalne związki z otoczeniem, czyli tzw. przywiązanie (attachment). Przywiązanie do norm „znaczących innych" pełni rolę prewencyjną, powstrzymując jednostkę przed zachowaniami o charakterze antyspołecznym. „Im mocniejsze jest bowiem przywiązanie do rodziny, przyjaciół, rówieśników, tym mniejsze prawdopodobieństwo przestępstwa" (Pieniążek, Stefaniuk 2005: 233). W rozumieniu Hirschiego, otoczenie jednostki jest wobec tego niejako reprezentantem porządku konformistycznego, zaś „przywiązanie” to inaczej mówiąc zinternalizowane w procesie socjalizacji normy i wartości społecznego mainstreamu. W sytuacji, gdy przywiązanie jednostki do jej społecznego otoczenia ulega osłabieniu, wzrasta prawdopodobieństwo 
przyjmowania przez nią postaw antyspołecznych, także o charakterze przestępczym. Drugim składnikiem więzi jednostki ze społeczeństwem jest tzw. zaangażowanie (commitment), stanowiące pewnego rodzaju ,inwestycję" (Siemaszko 1993: 240), jaką poczyniła, bądź czyni, dana osoba w porządek konformistyczny. Jest to najbardziej racjonalny składnik więzi jednostki z otoczeniem, nawiązujący, jak się wydaje, w swoich założeniach do teorii ekonomicznych. Działa bowiem na zasadzie chłodnej kalkulacji zysków i strat: im więcej jednostka ma do stracenia, tym mniejsze prawdopodobieństwo zachowań łamiących prawo i odwrotnie. Zaangażowanie oznacza sumę energii włożonej w działalność zgodną z porządkiem konformistycznym oraz jej efekty w postaci np. pozycji społecznej, prestiżu zawodowego, stanu majątkowego, posiadanych znajomości, posiadanej rodziny. Tym, co powstrzymuje jednostkę przed zachowaniami przestępczymi jest obawa przed utratą posiadanych zasobów ${ }^{4}$. Trzeci z wymienianych przez Hirschiego składników, tzw. zaabsorbowanie (involvement), jest w dużej mierze pochodną zaangażowania. Oznacza dosłownie wypełnienie czasu jednostki aktywnością zgodną ze społecznymi normami i oczekiwaniami. Zaabsorbowanie jest jednocześnie wymiarem określającym możliwość bądź też jej brak - (np. wskutek „natłoku obowiązków") podejmowania przez jednostkę działań o charakterze dewiacyjnym lub ściślej, przestępczym. Skłonności przestępcze jednostki są zatem niejako wypierane przez różnego typu aktywność ulokowaną w normatywnych ramach porządku konformistycznego. W sytuacji, w której stopień zaangażowania spada, paralelnie wzrasta ryzyko przestępstwa (dzieje się tak np. w sytuacji utraty stałego zatrudnienia, zerwania związku partnerskiego, utraty miejsca zamieszkania etc.). Ostatnim składnikiem więzi jednostki ze społeczeństwem jest tzw. przekonanie (belief) o zasadności lub nawet konieczności przestrzegania norm społecznych i postępowania zgodnie $\mathrm{z}$ wartościami obowiązującymi w danej zbiorowości. Słabnące przekonanie co do ich wiążącego charakteru jest pochodną słabnącej więzi z otoczeniem i konformistycznym porządkiem, tzn. słabnie, gdy słabną pozostałe elementy więzi jednostki ze społeczeństwem.

Wszystkie cztery elementy pozostają ze sobą w ścisłym związku i osłabienie jednego pociąga za sobą na ogół osłabianie pozostałych. Każdy z wymienionych składników może jednak niezależnie prowadzić do zachowań przestępczych (Hirschi 1969). Jednocześnie każdy z nich w mniej lub bardziej pośredni sposób odnosić się może do sytuacji rodzinnej jednostki, wydaje się jednak, że w kontekście analizy etiologii zachowań przestępczych nieletnich na pierwszy plan wysuwa się kategoria „,przywiązania”, jako że pozostałe odnoszą się przede wszystkim do okresu dorosłości (zaangażowanie i zaabsorbowanie), bądź też poziomu jed-

${ }^{4}$ Warto zwrócić uwagę, że Hirschi nawiązuje w tym punkcie do poglądów E. Durkheima, zgodnie z którego stanowiskiem człowiek jest ze swojej natury aspołeczny, zaś tym, co niejako „utrzymuje człowieka w ryzach” jest właśnie kontrola społeczna. W sytuacji, gdy owa kontrola zanika, prawdopodobieństwo zachowań antyspołecznych, w tym przestępczych, znacząco rośnie. 
nostkowej interpretacji norm i wartości społecznych, stanowiąc kategorię dosyć enigmatyczną (przekonania). Stąd też, prezentowane odniesienia do koncepcji Hirschiego nawiązywać będą przede wszystkim do pierwszego składnika więzi społecznej w ujęciu tego autora.

\section{RODZINNE UWARUNKOWANIA PRZESTĘPCZOŚCI NIELETNICH}

W ostatnich latach perspektywa kontroli społecznej i społecznych powiązań (social bonding approach) w kontekście analiz czynników sprawczych zachowań przestępczych, w tym także zachowań przestępczych młodzieży, znacząco zyskała na popularności. Prowadzone w tym okresie badania i analizy dotyczące osób trafiających do placówek wychowawczych i resocjalizacyjnych wskazują, że tak nieletni, jak i dorośli sprawcy przestępstw relatywnie często wywodzą się ze środowisk doświadczających silnej deprywacji na poziomie społecznym i ekonomicznym. Jednym z akcentowanych wymiarów życia społecznego, którego dotyczyć mogą istotne z kryminologicznego punktu widzenia deficyty w zakresie organizacji i dostępu do zasobów, jest funkcjonowanie w ramach małych grup społecznych, spośród których za najważniejszą uznaje się rodzinę.

Jednocześnie, jak już wcześniej zaznaczono, uwarunkowania rodzinne dosyć powszechnie uznaje się za jedną z dwóch (względnie trzech) najistotniejszych grup czynników w kontekście rozważań na temat kryminogenezy nieletnich sprawców czynów karanych. W świetle teorii kontroli społecznej stanowią one zbiór o potencjale szczególnym, przejawiającym się z jednej strony w pełnionej przez rodzinę funkcji prewencyjnej, tj. powstrzymywania jednostki (z natury aspołecznej) od przestępczej aktywności poprzez przekazywanie uznawanych za słuszne w ramach danej zbiorowości norm, wartości i wzorców osobowych, tworzenie odpowiednich warunków materialno-bytowych, zapewnianie poczucia bezpieczeństwa oraz realizację potrzeb emocjonalnych. $\mathrm{Z}$ drugiej zaś strony, rodzina może również dysponować istotnym potencjałem kryminogennym, zwłaszcza w sytuacji, gdy z jakichś powodów nie spełnia swoich podstawowych funkcji i/lub nie zaspokaja podstawowych potrzeb swoich członków.

Jak wskazuje Hołyst, wchodzący w konflikt z prawem nieletni w większości pochodzą z rodzin o skumulowanych niekorzystnych cechach (Hołyst 2006), wśród których zaspokajanie podstawowych potrzeb jednostki (a zwłaszcza dziecka) jest wysoce problematyczne. Badacze wskazują na różne występujące w życiu rodzinnym dysfunkcjonalne czynniki mogące prowadzić do zachowań przestępczych młodzieży. Lista owych czynników jest niezwykle długa i szczegółowa charakterystyka każdego z nich wykracza poza tematykę niniejszego opracowania, stąd też opisane zostaną tylko niektóre, najczęściej wskazywane przez badaczy 
problematyki przestępczości nieletnich lub/i szczególnie interesujące w kontekście przyjętej perspektywy teoretycznej. Zaliczyć można do nich:

1. Alkoholizm rodziców lub rodzeństwa - z badań prowadzonych w zakładach karnych przez A. Szymanowską wynika, że w grupie 358 badanych odbywających karę pozbawienia wolności (163 młodocianych, 115 dorosłych po raz pierwszy karanych oraz 80 recydywistów) zdecydowaną większość stanowiły osoby pochodzące $\mathrm{z}$ rodzin, w których występowały różnego rodzaju niekorzystne zjawiska, najczęściej związane z nadużywaniem lub uzależnieniem od alkoholu. Problemem tym dotkniętych było ogółem $40 \%$ badanych, przy czym wśród młodocianych aż $56,5 \%$. Połowa młodocianych doświadczających problemu alkoholowego w życiu rodzinnym przyznała również, że w przeszłości była ofiarą przemocy ze strony nadużywających alkoholu rodziców. Autorka ta zwraca ponadto uwagę, że w grupie młodocianych nie było ani jednej osoby, która wychowywała się w rodzinie bez żadnych poważnych problemów (Szymanowska 2003: 324-325).

2. Wykorzystywanie i zaniedbywanie dzieci - w kontekście zaniedbywania oraz wykorzystywania dzieci teoria kontroli społecznej zawiera sugestie, iż doświadczenie przez dziecko nadużyć ze strony rodziców prowadzi do zmniejszenia poczucia więzi z bliskimi, tym samym osłabiając przekonanie co do uznawanych przez nich norm i wartości. Do najszerzej cytowanych autorów zajmujących się związkami między problemem wykorzystywania dzieci a ich przestępczością należy C. Widom. Autorka ta, na podstawie sądowych rejestrów przestępstw wykorzystywania lub zaniedbywania dzieci, przeprowadziła longitudinalne badanie, porównując późniejszą karalność tej grupy z karalnością grupy kontrolnej. Z przeprowadzonych analiz wynika, że dzieci te znacznie częściej trafiały do aresztów śledczych, zarówno w wyniku przestępstw popełnianych jako nieletni, jak i jako dorośli (Maxfield, Widom 1996, za Farrington 2010a: 210). Co więcej, znacznie częściej niż w przypadku grupy kontrolnej przyczyną aresztowania w okresie nieletniości były przestępstwa z użyciem przemocy, zaś w odniesieniu do przestępstw popełnianych w życiu dorosłym stwierdzono zależność statystyczną z przestępstwami na tle seksualnym (Widom, Ames 1994, za: Farrington 2010a: 210). Psychiczne i fizyczne wykorzystywanie oraz zaniedbywanie mogą prowadzić do zmiany środowiska wychowawczego dzieci, np. w wyniku umieszczenia w placówce opiekuńczo-wychowawczej. Według danych raportu Social Exclusion Unit, przestępcy znacznie częściej niż osoby niekarane dorastają w placówkach opiekuńczo-wychowawczych: $27 \%$ populacji więziennej w stosunku do $2 \%$ populacji ogólnej. Co więcej, osoby te mają także na ogół dłuższe „kariery” kryminalne niż inni przestępcy. Autorzy raportu wskazują również, że blisko połowa (47\% mężczyzn i 50\% kobiet) spośród odbywających pod koniec lat 90 . karę pozbawienia wolności w więzieniach na terenie Wielkiej Brytanii przyznawała, że w dzieciństwie uciekała $\mathrm{z}$ domu rodzinnego. Odsetek takich osób w populacji ogólnej wynosił 11\% (Social Exclusion Unit, 2002: 18-22). 
3. Style i metody wychowawcze - Błachut i in. (2004: 335-336) wyróżniają 4 style wychowawcze: styl opiekuńczy (staranna opieka, łagodne sankcje, dominują pozytywne), styl autorytarny (staranna opieka, surowe sankcje, dominują negatywne), styl laissez-faire (żadna lub słaba opieka, łagodne sankcje), styl chaotycznego despotyzmu (żadna lub słaba opieka, surowe sankcje). W świetle teorii kontroli społecznej szczególnie „ryzykowny” wydaje się być styl laissez-faire, charakteryzujący się zaniedbywaniem ról opiekuńczych przez rodziców (co skutkuje słabą więzią z dziećmi), przy jednoczesnym stosowaniu łagodnych sankcji bądź ich niestosowaniu. Tym samym styl ten pozostawia kształtowanie osobowości dziecka grze przypadków, co wyraźnie zwiększa znaczenie innych (pozarodzinnych) środowisk socjalizujących, np. grup rówieśniczych. Zdaniem Hirshiego typ ten jest charakterystyczny dla rodzin przestępczych, tj. takich, $\mathrm{w}$ których rodzice lub/i rodzeństwo mają konflikty z prawem. Autor ten zwraca uwagę na kilka istotnych faktów empirycznych: w rodzinach przestępczych rodzice często nie mają informacji na temat aktualnego miejsca, w którym przebywają ich dzieci; rodzice nie znajdują na ogół czasu na dyskusję o istotnych sprawach dziecka (nawiązanie do zjawiska „dziedziczenia” przestępczości); rodzice rzadko objaśniają dzieciom zasady moralnego postępowania; w rodzinach przestępców brak jest możliwości kształtowania ideału ojca (Hirschi 1969). Jak się okazuje, styl laissez-faire nie jest wobec tego obcy kryminologii, choć z drugiej strony należy również mieć na względzie zainteresowania badawcze i teoretyczne Hirschiego, dla którego rozluźnienie więzi (zanik kontroli społecznej) między dzieckiem a rodzicami jest już samo w sobie czynnikiem o charakterze kryminogennym.

4. Wielkość rodziny i kolejność urodzenia - w badaniu Cambridge Study in Delinquent Development (o którym szerzej w dalszej części opracowania) stwierdzono, że wielkość rodziny, tj. liczebność rodzeństwa dodatnio korelowała zarówno z częstotliwością łamania prawa, jak i liczbą otrzymanych wyroków. Wyniki analiz prowadzonych przez zespół z Cambridge wykazały, że jeżeli badani chłopcy przed ukończeniem 10. roku życia mieli czworo lub więcej rodzeństwa, prawdopodobieństwo zaangażowania w działalność kryminalną wzrastało dwukrotnie (West, Farrington 1973). Jak wskazuje Farrington, istnieje wiele możliwych wytłumaczeń, dlaczego liczebność rodzeństwa zwiększa ryzyko przestępstwa wśród osób nieletnich. Spośród nich najbardziej prawdopodobne wydaje się zmniejszanie się możliwości poświęcenia uwagi rodzicielskiej każdemu dziecku z osobna, w miarę powiększania się gospodarstwa domowego ${ }^{5}$. Ten sam autor, powołując się na analizę Brownfielda i Sorenson, zwraca także uwagę, że istotną zmienną korelującą z zachowaniami przestępczymi młodzieży może być $\mathrm{w}$ dużych gospodarstwach domowych również kolejność urodzenia, przy czym zwiększone

\footnotetext{
${ }^{5}$ Zdaniem Hirschiego kontakty intymne między dzieckiem a rodzicami są niezwykle istotne z punktu widzenia kształtowania poczucia przywiązania do norm i wartości konformistycznego porządku.
} 
ryzyko zachowań przestępczych dotyczy zwłaszcza dzieci urodzonych później (Brownfield, Sorenson 1994, za: Farrington 2010a: 207).

W świetle teorii Hirschiego każdy spośród wymienionych czynników, występując łącznie lub niezależnie od pozostałych, może bez wątpienia wywierać ujemny wpływ na relacje i więzy łączące jednostkę z jej otoczeniem, zwłaszcza na linii dziecko-rodzic. Różni badacze wymieniają również takie kryminogenne zjawiska występujące w życiu rodzinnym, jak: brak emocjonalnej więzi rodzinnej, porzucenie rodziny przez jednego z rodziców, brak pozytywnych wzorców osobowych lub/i przestępcze wzorce zachowań (Hołyst 2009), niepełna struktura rodziny, złe pożycie rodziców, pozbawienie opieki (sieroctwo naturalne i społeczne), bezrobocie rodziców, niski poziom wykształcenia rodziców, zaniedbania w opiece nad dziećmi w związku z pracą zawodową rodziców, zaburzenia funkcjonalne rodziny (Żebrowski 1996: 72, za: Nowak, Wysocka 2001: 122), niekorzystna atmosfera wychowawcza, samotne rodzicielstwo, przemoc domowa (często w związku z nadużywaniem alkoholu), mała spójność rodziny, brak kontroli rodzicielskiej zachowań dzieci, brak spędzania wolnego czasu z dziećmi, brak rozmów rodziców z dziećmi (Kiliszek 2013).

Z perspektywy teoretyków i badaczy łączonych z kierunkiem kontroli społecznej, do zjawisk szczególnie niekorzystnych ze względu na swój kryminogenny potencjał należy jednak zjawisko wewnątrzrodzinnej transmisji zachowań przestępczych. Wśród jego badań i analiz tej problematyki wyróżnia się dwa typy: zajmujące się analizą czynników biologicznych (genetycznych predyspozycji do zachowań o charakterze antyspołecznym i przestępczym), oraz badające czynniki środowiskowe (wartości, normy i wzory zachowań utrwalane w toku socjalizacji i odtwarzane w dorosłym życiu przez dzieci przestępców) (Sakowicz 2009: 194). Ponieważ przedmiotem zainteresowania nie są biologiczne predyspozycje do działań przestępczych, lecz czynniki kryminogenne o charakterze społecznym, uwaga zostanie skoncentrowana na drugim nurcie.

Liczne badania i analizy problematyki dowodzą, że przestępczość jest zjawiskiem utrwalanym i odtwarzanym w międzypokoleniowym przekazie. Osoby wchodzące w konflikt z prawem wywodzą się często z rodzin, w których jedno z rodziców lub oboje byli przestępcami. Często mają też wchodzące w konflikt z prawem rodzeństwo. Przykładowo, w przywoływanym już badaniu Aleksandry Szymanowskiej, drugim najczęściej wskazywanym problemem występującym w rodzinie (po problemie alkoholowym) była karalność sądowa rodziców lub rodzeństwa, która dotyczyła 45\% rodzin młodocianych (Szymanowska 2003). W literaturze przedmiotu można się spotkać z tezą mówiącą o kilkukrotnie wyższym ryzyku występowania zachowań antyspołecznych i przestępczych wśród dzieci karanych rodziców niż w przypadku ich rówieśników rekrutujących się $z$ rodzin bez historii kryminalnej. Brakuje wprawdzie danych mogących w jednoznaczny sposób potwierdzić jej słuszność (Murray 2005: 447), znane są jednak 
liczne badania, w których dowiedziono istnienia silnych związków między przestępczością rodziców a skłonnościami do zachowań antyspołecznych ich dzieci. Szczególnie interesujące w tym kontekście wydają się przywoływane już badania lungitudinalne prowadzone przez zespół badaczy z Cambridge (Cambridge Study in Delinquent Develepment), w toku których wykazano, że bliskie pokrewieństwo (rodzic lub rodzeństwo) z osobą karaną jest silnym predykatorem kryminalnej przyszłości dzieci. Niemal połowa (48\%) badanych chłopców, z grupy, w której przynajmniej jedno z rodziców odbywało karę pozbawienia wolności zanim ci osiągnęli 10. rok życia, miała w przyszłości konflikty z prawem, podczas gdy w grupie kontrolnej ${ }^{6}$, tj. chłopców oddzielonych od swoich rodziców z innych przyczyn, było o blisko połowę mniej (25\%). Związek ten był silny niezależnie dla wszystkich czterech zmiennych: karany ojciec, matka, brat, siostra. Powtarzalność zachowań przestępczych (wszystkie cztery czynniki łącznie) dotyczyła aż 63\% badanych (30\% w grupie kontrolnej) (Farrington et al. 1996). Z kolei badania Pittsburgh Youth Study prowadzą do wniosku, że przestępczość młodzieży jest silnie związana z karalnością ojców, matek, braci, sióstr, wujków, cioć, dziadków i babć, przy czym najsilniejsze związki dotyczą karalności ojców (Farrington et al. 2001).

Oczywiście obecność w rodzinie kogoś z kryminalną przeszłością nie oznacza automatycznie, że: a) osoba ta nadal jest w tego typu działalność zaangażowana; b) każde dziecko wychowujące w się w takiej rodzinie również będzie miało skłonności do zachowań antyspołecznych i c) każde z nich będzie miało doświadczenia $\mathrm{z}$ łamaniem prawa w przyszłości. $Z$ analiz można jednak wnioskować, że dzieci wywodzące się z tzw. rodzin przestępczych znacznie częściej niż ich rówieśnicy z rodzin nie-przestępczych w przyszłości mają problemy z prawem, częściej też trafiają do placówek wychowawczych i resocjalizacyjnych. Przeprowadzone niedawno w Stanach Zjednoczonych badania wykazały, przykładowo, że w grupie ponad 18 tysięcy odbywających karę pozbawienia wolności rodziców aż 49\% miało w najbliższej rodzinie (rodzic, rodzeństwo, małżonka/ małżonek) przynajmniej jedną osobę, która również kiedyś była skazana na karę pozbawienia wolności, przy czym w 19\% badanych przypadków był to ojciec, a w 6\% - matka (Glaze, Maruschak 2008: 7). Dane Social Exclusion Unit wskazują natomiast, że w Wielkiej Brytanii więźniów spokrewnionych z inną osobą

${ }^{6} \mathrm{~W}$ badaniu tym wyróżniono 4 grupy kontrolne - chłopców, którzy: 1) w ciągu pierwszych 10 lat życia nie doświadczyli żadnego rodzaju separacji z rodzicem (dłużej niż na okres 1 miesiąca); 2) w ciągu pierwszych 10 lat życia zostali rozłączeni z przynajmniej jednym z rodziców na skutek jego hospitalizacji lub śmierci; 3) w ciągu pierwszych 10 lat życia zostali rozłączeni z przynajmniej jednym rodzicem z innych powodów niż jego hospitalizacja, śmierć lub odbywanie przez niego kary pozbawienia wolności; 4) chłopców, których rodzice odbywali karę pozbawienia wolności przed ich narodzinami i - jeśli w późniejszym okresie ponownie trafili do zakładów karnych - nie przed osiągnięciem przez nich 18 roku życia (Murray, Farrington 2008: 278). 
mającą za sobą pobyt w zakładzie karnym było $43 \%$, podczas gdy w populacji ogólnej - tylko 16\% (Social Exclusion Unit, 2002).

W kontekście teorii kontroli społecznej niezwykle istotnym predyktorem odtwarzania zachowań przestępczych przez kolejne pokolenia jest nie tyle fakt społecznego uczenia się zachowań przestępczych (na zasadzie identyfikacji z karanymi bliskimi osobami i naśladownictwa), na co m.in. zwracają uwagę autorzy Cambridge Study in Delinquent Develepment (zob. West, Farrington 1977), ale raczej ryzyko silnego osłabienia lub nawet całkowitego zerwania więzi rodzinnych w wyniku emocjonalnej (o czym była mowa wcześniej) lub/i fizycznej nieobecności rodziców, np. w związku odbywaniem przez nich kary pozbawienia wolności, która to sytuacja wiąże się na ogół z szeregiem innych, niejednokrotnie współwystępujących czynników, takich jak ograniczone możliwości utrzymywania kontaktu z rodzicem, dążenie do rekonstrukcji struktury rodzinnej bez udziału skazanego, rozpad rodziny, nieuczestniczenie rodzica w procesie wychowywania dziecka etc. Sam Hirschi był zdania, że nawet rodzice wchodzący w konflikt $\mathrm{z}$ prawem mogą niejednokrotnie kierować swoje dzieci w stronę zachowań prospołecznych, jako że w świetle jego założeń teoretycznych również i oni są reprezentantami porządku konformistycznego (Hirschi 1969).

Teoria kontroli społecznej w ujęciu Hirschiego, jak wcześniej już sygnalizowano, pomimo swej użyteczności analitycznej, posiada pewne istotne ograniczenia, które ze względu na jej reprezentatywność można by ulokować pod adresem całego kierunku kontroli społecznej. Jednym z najważniejszych, na które wskazuje Siemaszko (1993: 236), jest bez wątpienia założenie o istnieniu jednego wspólnego systemu wartości, który wyznają także jednostki naruszające prawo oraz inne istotne normy społeczne. Mówiąc inaczej, związki jednostki z jej otoczeniem mają w tym ujęciu zawsze charakter konformizujący, tj. „,ostrajający” zachowania jednostki do stanu zgodności z normami uznawanymi w ramach szerszej zbiorowości. Teoria ta nie zajmuje się tym samym możliwością odnalezienia dewiacyjnych zachowań wśród członków najbliższego otoczenia jednostki, ponieważ silna więź z otoczeniem i respektowanie jego norm i wartości zawsze prowadzi do przestrzegania norm społecznego mainstreamu.

\section{NIEFORMALNA KONTROLA SPOŁECZNA A PROCES ZMIANY ZACHOWAŃ PRZESTĘPCZYCH W CYKLU ŻYCIA}

Dobrze znane w kryminologii badania Gluecków (1934, za: Kiliszek 2013) są dowodem na to, iż „wczesny początek przestępczości jest powszechnie uważany za czynnik prognostyczny bardzo ujemny dla dalszego rozwoju dziecka" (Kiliszek 2013: 172). Co więcej, w licznych badaniach, zwłaszcza poświęconych zagadnieniom rozwoju kariery przestępczej w cyklu życia (life course approach) 
autorzy wskazują, że wczesna inicjacja przestępcza (zgodnie z ustaleniami badań z tego kierunku na ogół mająca miejsce między 8. a 14. rokiem życia) często prowadzi do relatywnie długiej i „,bogatej” kariery przestępczej (Farrington 2010: 251), co zresztą potwierdzają wcześniej prezentowane dane z raportu Social Exclusion Unit. W tym kontekście szczególnie istotną z punktu widzenia niniejszego opracowania kategorią jest „zmiana” zachowań przestępczych w cyklu życia jednostki. Do najbardziej wpływowych koncepcji związanych z tym zagadnieniem należy teoria nieformalnej kontroli społecznej J.H. Lauba i R.J. Sampsona?.

W ujęciu Lauba i Sampsona podstawową kategorią analityczną jest zmieniająca się w przebiegu biografii nieformalna kontrola społeczna, rozumiana jako siła więzi jednostki z rodziną, rówieśnikami, sąsiadami, środowiskiem szkolnym oraz obecnymi już w okresie dorosłości instytucjami społecznymi, do których autorzy zaliczają przede wszystkim małżeństwo oraz zatrudnienie. W koncepcji tej siła więzi zależy w głównej mierze od przywiązania jednostki (attachment), z jednej strony do „znaczących innych” oraz instytucji formalnych, z drugiej zaś do środowiska przestępczego i nieformalnych kręgów o charakterze kryminogennym. Przywiązanie zależy od czynników socjalizacyjnych, tj. dyscypliny i kontroli dziecka przez rodziców, natomiast czynniki strukturalne (np. przynależność klasowa, etniczność, wielodzietność, rodzice-przestępcy, rodziny rozbite) i indywidualne (np. niski poziom inteligencji, trudny temperament) mogą wywierać pośredni wpływ na nieformalną kontrolę społeczną (np. zła sytuacja materialna rodziny może wymagać od rodziców podjęcia pracy na wiele etatów, przez co będą mieć mniej czasu na realizację ról rodzicielskich; z kolei niski poziom inteligencji może się wiązać z nieumiejętnością oceny sytuacji czy podejmowaniem błędnych decyzji).

Wprowadzając w swej teorii kategorię „przywiązania” Laub i Sampson nawiązują w swoich założeniach do koncepcji kontroli społecznej Hirschiego. W przeciwieństwie do Hirschiego, Laub i Sampson przyjmują jednak, że więzi jednostki z otoczeniem nie muszą wcale prowadzić do zachowań zgodnych z normami i wartościami dominującymi w społeczeństwie. Porządek konformistyczny ma wobec tego charakter wielowymiarowy, zaś zachowania konformistyczne mogą w rzeczywistości być zachowaniami o charakterze przestępczym (np. w sytuacji przystosowania się do norm obowiązujących w grupie przestępczej). Tym samym, przywiązanie jednostki do wartości jej ,znaczących innych” (zwłaszcza członków rodziny) nie musi wcale pociągać za sobą respektowania wartości wyznawanych przez ogół społeczeństwa (np. jeśli w skład rodziny wchodzą osoby uwikłane w działalność o charakterze antyspołecznym lub przestępczym).

${ }^{7}$ Sami autorzy nie pomijają rzecz jasna tematyki etiologii zachowań przestępczych młodzieży. Została ona wyczerpująco opisana w ich publikacji Crime in the making. Pathways and turing points through life. Za ważne kryminogenne czynniki o podłożu rodzinnym badacze ci uznali m.in. alkoholizm rodziców, przestępczość rodziców oraz wielkość rodziny (Sampson, Laub 1993). 
Przywiązanie jednostki do otoczenia zmienia się niekiedy zasadniczo w toku biografii, np. stopniowa atrofia więzi osoby nieletniej ze „znaczącymi innymi” może prowadzić do wzrostu znaczenia grup rówieśniczych, co w sytuacji, gdy są to grupy o charakterze przestępczym może oznaczać dla jednostki zwrot w stronę alternatywnych (względem ogółu) norm, wartości czy wzorów osobowych. $\mathrm{Z}$ drugiej strony, zmiany na poziomie więzi jednostki z otoczeniem, jak już wspomniano, mogą w przypadku jednostek uwikłanych w działalność przestępczą prowadzić do paralelnych zmian zachowań przestępczych, w tym także do całkowitego wycofania (desistance) z kariery kryminalnej.

Zgodnie z najważniejszymi ustaleniami kryminologicznych badań zmiany zachowania przestępczego w cyklu życia, przewaga zachowań przestępczych osiąga szczyt w późnych latach młodzieńczych, między 15. a 19. rokiem życia, a następnie, $\mathrm{z}$ biegiem lat, niezależnie od profilu działalności kryminalnej, stopniowo maleje (Farrington 2010). Zdania co do przyczyn tej tendencji są jednak w środowisku kryminologicznym dosyć podzielone. Część badaczy zwraca uwagę, że spadek aktywności kryminalnej łączy się z ogólnym spadkiem aktywności, związanym z biologicznymi uwarunkowaniami człowieka. Nawet w grupie wielokrotnych recydywistów, wielokrotnie karanych w okresie wczesnej i późnej młodości, obserwuje się z biegiem lat proces swoistego „wypalania się" przestępców, tzn. wyraźny spadek liczby popełnianych przestępstw, niezależnie od profilu kryminalnej działalności. Jego przyczyną jest, zdaniem wielu, proces starzenia, związany z ogólnym spadkiem witalności jednostki, co na gruncie polskim zostało dosadnie określone mianem „resocjalizacji przez uwiąd starczy” (Kowaluk 1999). Według Lauba i Sampsona zmiany te mają jednak raczej związek z czynnikami stricte środowiskowymi, niż biologicznymi uwarunkowaniami człowieka. Autorzy ci zwracają w tym kontekście uwagę na charakterystyczne dla życia dorosłego, zwłaszcza po 20. roku życia, zmiany związane z wchodzeniem w nowe (w perspektywie biograficznej jednostki) role społeczne ${ }^{8}$. Ważne wydarzenia życiowe, o których mowa, są swoistymi punktami zwrotnymi w biografii jednostki, do których, obok uzyskania dobrze płatnej i przynoszącej satysfakcję pracy i wstąpienia do wojska (oraz procesem socjalizacji wtórnej w ramach tej instytucji), zaliczają małżeństwo (zwłaszcza tzw. dobre małżeństwo, tj. takie, które powstrzymuje jednostkę od zachowań przestępczych, kontaktów z kolegami-przestępcami). Małżeństwo jest przez Lauba i Sampsona uznawane za najsilniejszy typ punktów zwrotnych pod względem potencjału prewencyjnego względem aktywności przestępczej jednostki (Laub, Sampson 2003).

${ }^{8}$ Odwołując się do koncepcji Hirshiego można też zauważyć, iż okres po 20. roku życia wiąże się na ogół z wchodzeniem w struktury zwiększonej aktywności o charakterze konformistycznym (zwł. na drodze podjęcia pracy zawodowej). W tym kontekście, pod względem analitycznym, na znaczeniu zaczyna zyskiwać kategoria zaabsorbowania i zaangażowania, które w przekonaniu autora, jak wcześniej zaznaczono, w mniejszym stopniu odnoszą się do okresu wczesnej młodości aniżeli kategoria przywiązania. 
Autorzy ci zwracają uwagę, że biografie wielu nieletnich i młodocianych przestępców charakteryzuje często wyraźny kontrast między okresem wczesnej młodości a dorosłością w kontekście po pierwsze - organizacji życia i funkcjonowania $w$ ramach formalnych i nieformalnych instytucji społecznych, po drugie - doświadczeń związanych z łamaniem prawa9. Obserwowanej w okresie adolescencji chaotyczności w działaniu, przejawiającej się niekiedy również w charakterze popełnianych przestępstw, oraz ogólnej dezorganizacji życia przeciwstawiają zauważalną stabilizację w życiu dorosłym (Laub, Sampson 2003: 118-123). Efekt prewencyjny założenia rodziny (zależność statystyczna między instytucją małżeństwa a redukcją zachowań przestępczych wśród badanych) został przez nich oszacowany na poziomie $40 \%$. Warto nadmienić, że niektórzy badacze wskazują także na prewencyjną funkcję rodzicielstwa i poważnych, choć niesformalizowanych związków partnerskich (np. kohabitacja). Z drugiej strony, późniejsze rozstanie, separacja lub rozwód z partnerem mogą prowadzić do powrotu na drogę przestępczą (Farrington 2010).

\section{PODSUMOWANIE}

W ostatnich latach perspektywa kontroli społecznej i powiązania społecznego w odniesieniu do analiz etiologii oraz zmiany zachowań przestępczych osób nieletnich zyskała znów na popularności. Nieformalna kontrola społeczna, najbardziej charakterystyczna dla małych grup społecznych, takich jak rodzina, oparta jest na wieloletnich więziach wspólnoty $\mathrm{i}$ - poprzez proces socjalizacji oraz za pomocą tzw. subtelnych środków kontroli (np. reprymenda słowna, upomnienie, perswazja) - ma na celu wywarcie wpływu na jednostkę w stronę postaw i zachowań przepisanych przez normy powszechnie uznawane w danej sytuacji (por. Podgórecki 2010: 8). W kontekście poczynionych ustaleń można wskazać pewne istotne implikacje praktyczne, związane z jednej strony z przeciwdziałaniem kryminogenezie nieletnich, z drugiej zaś z czynnikami prewencyjnymi związanymi z tranzycją młodych osób w życie dorosłe.

Po pierwsze, wskazywane przez różnych badaczy i określane jako kryminogenne, deficyty występujące w życiu rodzinnym nieletnich sprawców przestępstw kierują uwagę w stronę perspektywy wykluczenia społecznego. Kryminogenny charakter zjawiska wykluczania społecznego jest na gruncie socjologicznie zorientowanych analiz kryminologicznych na ogół niekwestionowany (Hołyst 2007: 116) i uznaje się, że ze zjawiskiem przestępczości zarówno dorosłych, jak i nieletnich pozostaje w silnej, obustronnej relacji. Ze względu na nasilenie czynników

${ }^{9}$ Badacze ci celowo pomijają w swoich analizach tzw. przestępstwa przypadkowe, tj. związane z wypadkami losowymi, jak np. część przestępstw drogowych. 
o potencjale kryminogennym, środowiska dotknięte daleko idącą deprywacją społeczną - np. osób bezrobotnych, uzależnionych od alkoholu lub narkotyków, rodzin bezradnych w sprawach opiekuńczo-wychowawczych, czy dzieci ulicy - uznawane są więc, niezależnie od przyjmowanej perspektywy teoretycznej, za grupy szczególnego ryzyka. $Z$ tego samego powodu, w społecznej percepcji, bywają definiowane jako prawdopodobne źródło zagrożenia dla porządku społecznego, co zdaniem wielu badaczy (kojarzonych głównie z nurtem labellingu) może mieć realny wpływ na interpretację ich zachowań przez środowisko lokalne lub nawet organy ścigania czy wymiar sprawiedliwości (zob. Cohen, Short 1961). Istnieje wobec tego potrzeba implementacji działań o charakterze profilaktycznym, mobilizujących zasoby na poziomie jednostkowym i rodzinnym z jednej strony, przeciwdziałających procesom atrofii powiązań jednostki ze społeczeństwem, $\mathrm{z}$ drugiej zaś działań wdrażanych na poziomie systemowym w formie programów prewencyjnych i formułowania innowacyjnych narzędzi polityki społecznej przeciwdziałających procesom wykluczania społecznego.

Po wtóre, istnieje duże zapotrzebowanie na wskazanie nowych środków i obszarów mobilizacji społecznej w celu ograniczania procesu pogłębiania marginalizacji nieletnich i małoletnich opuszczających placówki wychowawcze i resocjalizacyjne. Badania zajmujące się kategorią zmiany zachowań przestępczych w cyklu życia jednostki przyjmują w tym kontekście presupozycję, zgodnie z którą za „wycofanie” z kariery kryminalnej oraz ponowne włączanie (się) byłych pensjonariuszy wspomnianych placówek w nurt mainstream society odpowiadać mogą nie tylko intencjonalne, sformalizowane oddziaływania korekcyjne, takie jak realizowane $w$ ramach tych i innych instytucji, ale też lub nawet przede wszystkim czynniki niezwiązane ze sformalizowaną działalnością korekcyjno-inkluzyjną, np. w formie szeroko rozumianego wsparcia i związków z rodziną, tzw. dobrej pracy, czy kontaktów ze znajomymi nie związanymi z podkulturą przestępczą. Jak wskazuje Shadd Maruna (et al. 2004: 11), kryminologiczne studia nad „wycofaniem” z działalności przestępczej wyrosły poniekąd z krytyki „modelu medycznego" rehabilitacji jednostek dopuszczających się aktów łamania prawa, pierwotnie odnosząc się do tych spośród nich, które zmieniają swoje zachowania ( $\mathrm{tj}$. zaprzestają działalności o charakterze przestępczym) bez zewnętrznej ingerencji instytucji prowadzących oddziaływania korekcyjne. Wydaje się jednak, iż nie istnieją żadne konkretne przesłanki ku temu, by traktować oba typy „wycofania” z dalszej kariery przestępczej rozłącznie, lub tym bardziej w opozycji jedno do drugiego. Tak zwani spontaneous desisters, czyli zmieniający swoje zachowania niezależnie od zinstytucjonalizowanej, formalnej ingerencji, najczęściej poszukują wsparcia w swoich środowiskach i niejednokrotnie też otrzymują je w dużych ilościach, zaś to, czy jego źródłem są wytrenowani terapeuci lub wychowawcy, kręgi koleżeńskie, czy wreszcie rodzina, nie ma większego znaczenia jeżeli przynosi wymierne efekty (por. Maruna et al. 2004: 12-13). 


\section{BIBLIOGRAFIA}

Błachut J., Gaberle A., Krajewski K. (2004), Kryminologia, Arche s.c., Gdańsk.

Brownfield D., Sorenson A. (1994), Sibling size and sibling delinquency, „Deviant Behavior”, vol. 15.

Cohen A., Short J. (1961), Juvenile delinquency, [w:] R.K. Merton, R. Nisbet (eds.), Contemporary Social Problems, Harcourt, Brace and World, Inc., New York.

Farrington D. (2010a), Family influences on delinquency, [w:] D.W. Springer, A.R. Roberts (eds.), Juvenile Justice and Delinquency, Jones and Bartlett, Sudbury, MA.

Farrington D. (2010b), Life course and developmental theories in criminology, [w:] E. Mclaughlin, T. Newburn, The SAGE Handbook of Criminological Theory, SAGE, London.

Farrington D., Jolliffe D., Loeber D., Stouthamer-Loeber M., Kalb L.M. (2001), The concentration of offenders in families and family criminality in the prediction of bys delinquency...???

Farrington D., Loeber D., Stouthamer-Loeber M., Van Kammen W. (1996), Self-reported delinquency and a combied delinquency seriousness scale based on boys, mothers and teachers, „Criminology", vol. 34 .

Glaze L., Maruschak L. (2008), Parents in prison and their minor children, Bureau of Justice Statistics, Washington, D.C.

Hirschi T. (1969), Causes of delinquency, The University of California Press, Berkeley.

Hołyst B. (2006), Wiktymologia, Lexis Nexis, Warszawa.

Hołyst B. (2007), Socjologia kryminalistyczna, t. 1, Lexis Nexis, Warszawa.

Hołyst B. (2009), Kryminologia, Lexis Nexis, Warszawa.

Jefferson T. (2010), Psychosocial criminology, [w:] E. Mclaughlin, T. Newburn, The SAGE Handbook of Criminological Theory, SAGE, London.

Kiliszek E. (2013), Czynniki ryzyka sprzyjające niedostosowaniu społecznemu i przestępczości nieletnich, [w:] Profilaktyka społeczna i resocjalizacja, t. 21, Instytut Profilaktyki Społecznej i Resocjalizacji, Warszawa.

Kowaluk K. (1999), Resocjalizacja przez „,uwiąd starczy”, „Forum Penitencjarne”, nr 4.

Laub J., Sampson R. (2003), Shared beginnings, divergent lives. Delinquent boys to age 70, Harvard University Press, Cambridge, MA.

Maruna S., Immarifeon R., LeBel T. (2004), Ex-offender reintegration: theory and practice, [w:] Maruna, Immarifeon (eds.) "After crime and punishment. Pathways to offender reintegration", Routledge, London-New York:

Maxfield M., Widom C. (1996), The cycle of violence. Revisited 6 years later, „Archives of Pediatrics \& Adolescent Medicine", vol. 150(4).

Murray J. (2005), The effects of imprisonment on families and children of prisoners, [w:] A. Liebling, S. Maruna (eds.), The effects of imprisonment, Cullompton, Willan Publishing, Devon.

Murray J., Farrington D.P. (2008), Parental imprisonment: Long-lasting effects on boys'internalizing problems through the life course, „Development and Psychology”, vol. 20.

Nowak A., Wysocka E. (2001), Problemy i zagrożenia społeczne we współczesnym świecie, Wydawnictwo Naukowe „Śląsk”, Katowice.

Pieniążek A., Stefaniuk M. (2005), Socjologia prawa. Zarys wykładu, Zakamycze, Kraków:.

Podgórecki A. (2010), Kontrola społeczna trzeciego stopnia, [w:] Profilaktyka społeczna i resocjalizacja, t. 15, Instytut Profilaktyki Społecznej i Resocjalizacji, Warszawa.

Sakowicz T. (2009), Badania rodzin więźniów w literaturze zachodniej, [w:] F. Kozaczuk (red.), Prawne i socjokulturowe uwarunkowania profilaktyki społecznej i resocjalizacji, Wydawnictwo Uniwersytetu Rzeszowskiego, Rzeszów.

Sampson R., Laub J. (1993), Crime in the making. Pathways and turning points through life, Harvard University Press, Cambridge, MA. 
Siemaszko A. (1993), Granice tolerancji. O teoriach zachowań dewiacyjnych, PWN, Warszawa.

Social Exclusion Unit (2002), Reducing re-offending by ex-prisoners. Report by the Social Exclusion Unit, Office of the Deputy Prime Minister, London.

Szymanowska A. (2003), Więzienie i co dalej?, Wydawnictwo Akademickie „Żak”, Warszawa.

West D., Farrington D. (1973), Who becomes delinquent?, Heinemann, London.

West D., Farrington D. (1977), The delinquent way of life, Heinemann, London.

Widom C., Ames M. (1994), Criminal consequences of childhood sexual victimization, „Child Abuse and Neglect", vol. 18.

Żebrowski J. (1996/94?), Rodzinne uwarunkowania przestępczości nieletnich, [w:] S. Kawula, H. Machel, (red.), Młodzież a współczesne dewiacje i patologie społeczne: diagnoza, profilaktyka, resocjalizacja, Wydawnictwo A. Marszałek, Gdańsk-Toruń.

\section{Familial conditions of juvenile delinquency (in the light of informal social control theories) \\ Summary}

Social control as a set of means used in order to sustain social bonds and therefore to maintain social order, offers to criminology a category of special epistemological value, both in context of etiology of criminal behavior, and in the context of change of criminal behavior in the life course of the individual. Research and analyses indicate that bonds connecting the individual to his/her closest social environment can be - in both of the mentioned contexts - important or even determinant factors. That is why specialists in the criminological field, investigating the phenomenon of change of individual's criminal behavior through life tend to turn their increasing attention towards informal relations of juvenile, as well as adult offenders and their functioning in small social groups, of which recognized as the most important is family. The aim of this article is to characterize some of the relations between youth criminality and their family life in the light of criminological theories of informal social control.

Keywords: youth offending, social control, social tais, change in criminal behaviour. 